\title{
Our Editorial Board
}

\author{
Board: \\ Debbie Bogenschutz \\ Coordinator of Information \\ Services Johnnie Mae Berry \\ Library Cincinnati State \\ College Library \\ 3520 Central Parkway \\ Cincinnati, $\mathrm{OH} 45223$ - \\ 2690 \\ dabogens@fuse.net
}

\section{Lesley Farmer}

California State University, Department of

Advanced

Studies in Education and Counseling

1250 Bellflower Blvd., Long Beach, CA

90840 1farmer@csulb.edu

\section{Karen McQuillen}

Manager, Library Services, Brigham Library Educational

Testing Service, Rosedale Road

Princeton, NJ 08541

kmcquillen@ets.org
Editor:

Jacqueline Snider

ACT, Information Resource Center

Iowa City, IA 52243

education.libraries@gmail.com

\section{Book Review Editor:}

Kim Bloedel

Kimberly Bloedel

Marvin A. Pomerantz Business Library, University of Iowa

Iowa City, IA

kimberly-bloedel@uiowa.edu

\section{Education Division, SLA (2014) \\ Chair: Maya Kucij \\ Chair-Elect: Karen S. Croneis \\ Past Chair: Lesley Farmer \\ Secretary/Treasurer: David Shumaker}

\begin{abstract}
Education Libraries (ISSN 0148-1061), an online, refereed publication of the Education Division, Special Libraries Association (SLA), is published two times a year (Summer/Winter). This journal provides immediate open access to its content on the principle that making research freely available to the public supports a greater global exchange of knowledge. Issues of Education Libraries are available in full-text from 1992 to the present on the SLA Education Division's website at http://education.sla.org/. The journal is indexed in EBSCOhost's Education Collection, Library Literature and Information Science Index/Full-Text, and the ERIC database. Permission to reprint articles must be obtained in writing from the Editors (or the original sources where noted). Opinions expressed in articles and book reviews are those of the authors and do not necessarily represent the views of the editors, Editorial Committee, or the members of the SLA Education Division.
\end{abstract}

